UNDERGRADUATE RESEARCH IN NATURAL AND CLINICAL SCIENCE AND TECHNOLOGY (URNCST) JOURNAL Read more URNCST Journal articles and submit your own today at: https://www.urncst.com

\title{
DeSCIpher 2021 Undergraduate Sciences Case Competition: Space Debris
}

Jessica Moreira, BHSc Student [1]*, Eun Young Bae, BHSc Student [2], Lily-Thao Nguyen, BHSc Student [2], Deep Shah, BSc Student [1], Gerthan Selvanathan, BSc Student [3], Abigail Jacob, BHSc Student [2], Karen M. Zhao, BHSc Student [2], Shaheer Nadeem, BHSc Student [2], Renee Hu, BHSc Student [2], Alisa Vorotyntseva, BSc Student [4], Aishwaria Maxwell, BHSc Student [2]

[1] Department of Biochemistry and Biomedical Sciences, McMaster University, Hamilton, Ontario, Canada L8S 4L8

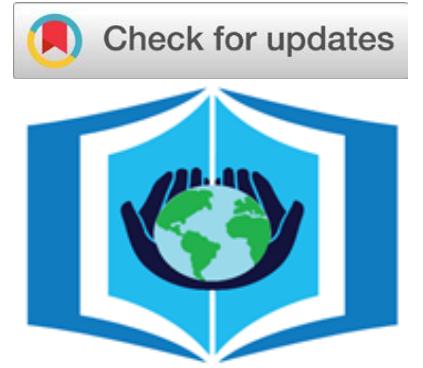

URNCST Journal

"Research in Earnest"

[2] Bachelor of Health Sciences Program, McMaster University, Hamilton, Ontario, Canada L8S 4L8

[3] Department of Psychology, Neuroscience and Behaviour, McMaster University, Hamilton, Ontario, Canada L8S 4L8

[4] Department of Kinesiology, McMaster University, Hamilton, Ontario, Canada L8S 4L8

*Corresponding Author: moreiraj@mcmaster.ca

\begin{abstract}
DeSCIpher: McMaster University Life Sciences Competition (MULSC) brings together undergraduate students of various science, technology, engineering, and mathematics (STEM) disciplines to collaboratively compete in a one-day competition. An integral aspect of this competition is the Inquiry Challenge, where a pressing issue is presented to all participants. In teams of three to four individuals, participants are asked to think of creative, evidence-based, and feasible solutions to the proposed prompt. In 2021, the Inquiry Challenge centered on 'space debris' and its detrimental effects on Earth. Participants were asked to find in-depth peer-reviewed articles from reputable sources to determine appropriate courses of action that address its issues. An infographic and short abstract were then prepared by the participants, to showcase their findings; the latter are presented in this abstract book. The top four abstracts were chosen based on a predetermined rubric. Overall, DeSCIpher hopes to highlight its commitment to knowledge and passion for the interdisciplinary sciences through its Inquiry Challenge, and the competition as a whole. The McMaster Students Union website featuring information about DeSCIpher can be reached at https://msumcmaster.ca/initiative/descipher/.
\end{abstract}

Keywords: DeSCIpher; case competition; inquiry challenge; space debris; pollution; collision; satellite; disposal; space exploration; innovation

Table of Contents

Infographic Presentations pg. A1-A3

\section{Conference Abstracts}

Note: These abstracts have been reproduced directly from the material supplied by the authors, without editorial alteration by the staff of the URNCST Journal. Insufficiencies of preparation, grammar, spelling, style, syntax, and usage are the authors.

\section{$\underline{\text { Infographic Presentations }}$}

The huff-and-puff approach: A proposed solution to space debris removal John Chiong, BHSc Student [1], Vivian Li, BHSc Student [1], Megan Lowe, BHSc Student [1] [1] Bachelor of Health Sciences Program, McMaster University, Hamilton, Ontario, Canada L8S 4L8

Space debris describes a collection of non-functional artificial objects such as old satellites and fragments of machinery. For decades, the accumulation of space debris in low-Earth orbit has been a serious concern, causing collisions with existing satellites and disrupting communication infrastructure as a result. Therefore, an effective and feasible solution is needed to resolve this issue. After comparing various space debris removal techniques reported by different organizations, specifically, the National Academies of Science, Engineering, and Medicine, NASA, as well as ScientificDirect, we believe the "huffing 
UNDERGRADUATE RESEARCH IN NATURAL AND CLINICAL SCIENCE AND TECHNOLOGY (URNCST) JOURNAL Read more URNCST Journal articles and submit your own today at: https://www.urncst.com

and puffing method" holds the greatest potential to remove space debris. Huffing and puffing involves a generator firing focused pulses of atmospheric gases from the Earth towards targeted debris, causing it to burn upon re-entry. These pulses will fall back into the atmosphere, leaving no residual traces. Preliminary results prove this to be effective in removing debris from both low and high orbits by changing the velocity of the pulse. Unlike techniques that require placing solid materials in space such as solar sails and space balloons, this method minimizes the risk of creating more debris. Despite the high fuel cost used to create pulses, continued testing and improvements to optimize fuel consumption will provide cost-effective results. Thus, the huffing and puffing technique should be considered as a promising removal solution to the pressing issue of space debris.

Electrodynamic and laser space debris: A research study Matthew Badal-Badalian, BEng Student [1], Edward Shen, BSc Student [2], Manish Angrish, BSc Student [2]

[1] Department of Electrical and Computer Engineering, McMaster University, Hamilton, Ontario, Canada L8S 4L8

[2] Department of Biochemistry and Biomedical Sciences, McMaster University, Hamilton, Ontario, Canada L8S 4L8

Space debris is an alarming problem that researchers around the globe have been working to solve. While the size of the particles may vary dramatically, the overall effect of this debris can be devastating upon collision with devices such as satellites, telecommunicators, etc. To inquire more about this situation, information from the NASA database was used. From there, it was found that there are approximately 200 million objects orbiting close to the earth. In addition, it was found that there were several different techniques currently under investigation to eliminate space debris. In order to solve this problem, we have decided to create a dual-debris model which uses a laser-guided and electrodynamic approach. The first process involves short-wavelength laser pulses that focus on debris greater than $10 \mathrm{~cm}$ in diameter, generating plasma plume ejections that decrease orbital velocity. This approach avoids direct contact with debris which may otherwise cause damage to equipment. The electrodynamic approach will be used to attract and dispose of materials less than $10 \mathrm{~cm}$ in diameter with an electrically charged net dispatched by a satellite, which is then guided towards the Earth. This method serves as a costefficient method of eliminating large amounts of small debris. Both methods will allow targeted debris to approach and disintegrate in the earth's atmosphere or fall into the ocean. Overall, the need to discard space debris is essential to future space exploration studies and, creating a dual-debris model with a laser-guided approach and electrostatic net can effectively solve this problem.

Addressing issues of space debris and potential solutions

Elaine Ho, BHSc Student [1], Esther Su, BHSc Student [1], Rebecca He, BHSc Student [1], Roxxannia Wang, BEng BME Student [2]

[1] Bachelor of Health Sciences Program, McMaster University, Hamilton, Ontario, Canada L8S 4L8

[2] Department of Engineering, McMaster University, Hamilton, Ontario, Canada L8S 4L8

Space debris poses a growing threat to satellites and spaceflight. It is a problem that requires attention from research institutions, government departments, the general public and industries alike to tackle. The short-term and long-term solutions were obtained from many online open resources such as NASA, PubMed, science journals and blogs, news articles, as well as personal envisioning. Short-term solutions are better structured to relieve the current large accumulation of space debris orbiting the Earth. These solutions consist of traditional and matured technologies that are currently widely used, such as attaching nets, harpoons or spears onto satellites to be launched into programmed orbit. Additionally, technologies such as lasers may be further adapted-mounting retroreflectors on satellites permits an increase in laser range of $3000 \mathrm{~km}$, also enabling their use during daytime. Long-term technical solutions focus on the continued development of novel technologies. The primary solution is NASA's Modelling and Tracking system that evaluates collision risk of debris as small as $1 \mathrm{~mm}$, with an alert and action system when safety limit is reached. Programmed deorbiting of obsolete satellites might also be pursued, with an additional component of de-orbiter machines that identify, attach to and deorbit such satellites. The involvement of private and government organizations should not be neglected. International agreements and collaborations with industry will be necessary to put these solutions into practice. With a public database of space debris information shared among the participating countries, more future technologies and forces will be gathered to prevent further accumulation of space debris. 
UNDERGRADUATE RESEARCH IN NATURAL AND CLINICAL SCIENCE AND TECHNOLOGY (URNCST) JOURNAL Read more URNCST Journal articles and submit your own today at: https://www.urncst.com

\author{
An endgame for space debris \\ Adrian Wong, BHSc Student [1], Anjelica Shrestha, BHSc Student [1], Sonvin Yim, BSc Student [2], Murad Taher, BSc \\ Student [2] \\ [1] Bachelor of Health Sciences Program, McMaster University, Hamilton, Ontario, Canada L8S 4L8 \\ [2] Faculty of Science, McMaster University, Hamilton, Ontario, Canada L8S 4L8
}

Space debris is an issue that has the potential to threaten humanity's dependence on satellites and desire for continued space exploration. According to existing studies, space debris, defined as man-made machinery that has been discarded into space, comprises more than $90 \%$ of large objects orbiting the Earth. Collisions of satellites with even small particles can be catastrophic and subsequently form more space debris. A drastic increase in space debris may lead to Kessler syndrome, in which the dense concentration of orbiting space debris increases the likelihood of object collision, starting a cascade of collisions that produces even more space debris. An approach to reduce the concentration of space debris can be established using a collaborative tracking system. The FGAN Tracking and Imaging Radar can be combined with high-frequency pulses to detect space debris within its orbit. Once the debris has been detected, a signal will release a net to collect debris of all sizes and types for disposal. When the threshold capacity is reached, the detachable storage capsule will be ejected towards the Earth and de-orbited so it can disintegrate into the atmosphere. This economically feasible and sustainable system of collection may bring about an effective solution for the problem of space debris.

\title{
Conflicts of Interest
}

The authors declare that they have no conflict of interests.

\section{Authors' Contributions}

All authors contributed to the development and editing of the abstract book.

\section{Acknowledgements}

The authors wish to acknowledge the incredible work of the last six DeSCIpher teams and the Editor, Jeremy Ng, for his continued support of DeSCIpher and this abstract book.

\author{
Article Information \\ Managing Editor: Jeremy Y. Ng \\ Article Dates: Received Apr 16 21; Published Apr 2621
}

\section{Citation}

Please cite this article as follows:

Moreira J, Bae EY, Nguyen LT, Shah D, Selvanathan G, Jacob A, Zhao KM, Nadeem S, Hu R, Vorotyntseva A, Maxwell A. DeSCIpher 2021 Undergraduate Sciences Case Competition: Space Debris. URNCST Journal. 2021 Apr 26: 5(4).

https://urncst.com/index.php/urncst/article/view/275

DOI Link: https://doi.org/10.26685/urncst.275

\section{Copyright}

(C) Jessica Moreira, Eun Young Bae, Lily-Thao Nguyen, Deep Shah, Gerthan Selvanathan, Abigail Jacob, Karen M. Zhao, Shaheer Nadeem, Renee Hu, Alisa Vorotyntseva, Aishwaria Maxwell. (2021). Published first in the Undergraduate Research in Natural and Clinical Science and Technology (URNCST) Journal. This is an open access article distributed under the terms of the Creative Commons Attribution License (https://creativecommons.org/licenses/by/4.0/), which permits unrestricted use, distribution, and reproduction in any medium, provided the original work, first published in the Undergraduate Research in Natural and Clinical Science and Technology (URNCST) Journal, is properly cited. The complete bibliographic information, a link to the original publication on http://www.urncst.com, as well as this copyright and license information must be included. 


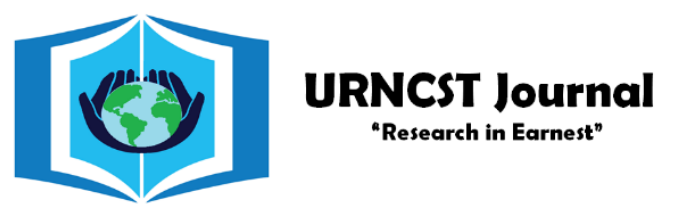

\section{Funded by the Government of Canada}

\section{Canadà̀}

Do you research in earnest? Submit your next undergraduate research article to the URNCST Journal!

| Open Access | Peer-Reviewed | Rapid Turnaround Time | International | | Broad and Multidisciplinary | Indexed | Innovative | Social Media Promoted |

Pre-submission inquiries? Send us an email at info@urncst.com | Facebook, Twitter and LinkedIn: @ URNCST Submit YOUR manuscript today at https://www.urncst.com! 